\title{
Diffusion and Chemical Shift Magnetic Resonance Imaging Properties of Lumbar Bone Marrow; Correlation with Osteoporosis
}

\author{
Lomber Kemik Iliğinin Difüzyon ve Kimyasal Kayma Manyetik Rezonans Görüntüleme \\ Özellikleri; Osteoporozla Korelasyon
}

(D) Betül Kızıldağ, (D) Mehmet Akif Sarıca, (D) Nursel Yurttutan

Kahramanmaraş Sütçü Imam University Faculty of Medicine, Department of Radiology, Kahramanmaraş, Turkey

\section{Abstract}

Objective: To investigate whether or not diffusion-weighted imaging (DWI) of vertebral bone marrow or dual-echo chemical shift imaging (CSI) achieved by magnetic resonance imaging (MRI) can be used in the diagnosis of osteoporosis.

Materials and Methods: Twenty-nine postmenopausal women patients (mean age 53.9 \pm 9 years) who underwent upper abdominal MRI and dual-energy X-ray absorptiometry (DXA) were included in the study retrospectively. A total of 87 lumbar vertebras which appropriate were divided into subgroups as normal, osteopenic and osteoporotic according to T-scores. Apparent diffusion coefficient (ADC) values were calculated from DWI and signal intensities (SI) that measured in T1 dual-echo sequences were compared between groups. The fat fractions of the vertebral body were measured based on the signal intensity index and vertebral spleen ratio (VSR) formulas previously used for adrenal adenomas.

Results: The mean vertebral ADC values were $0.61 \pm 0.1 \times 10-3 \mathrm{~mm}^{2} / \mathrm{s}$ in the normal group, $0.59 \pm 0.1 \times 10-3 \mathrm{~mm}^{2} / \mathrm{s}$ in the osteopenic group, and $0.56 \pm 0.1 \times 10-3 \mathrm{~mm}^{2} / \mathrm{s}$ in the osteoporotic group and there was no significant difference between them. The SI in out-of-phase sequence, SI index, and VSR were able to discriminate the osteoporotic group that had sustained fracture risks from the healthy and osteopenic ones. The sensitivities of the out-of-phase SI, SI index and VSR were $65.2 \%, 61.1 \%$ and $71 \%$, respectively, while their specificities were $61.1 \%$, $63.8 \%$, and $61.1 \%$, respectively.

Conclusion: The diffusion properties of bone marrow are not fully affected by osteoporosis. The DXA scores appear to be moderately related to the chemical composition of bone marrow rather than its cellularity. CSI based fat quantification can be a referrer in the decision to initiate treatment by giving an idea of the presence of osteoporosis.

Keywords: Osteoporosis, bone mineral density, magnetic resonance imaging, chemical shift imaging, diffusion-weighted imaging

\section{Öz}

Amaç: Osteoporoz tanısında vertebra kemik iliğinin difüzyon ağırlıklı görüntülemesinin (DAG) ya da dual-eko kimyasal kayma manyetik rezonans görüntülemenin (MRG), kullanılıp kullanılamayacağını irdelemektir.

Gereç ve Yöntem: Çalışmaya üst abdomen MRG ve dual enerji X-ray absorbsiyometri (DXA) yapılan 29 postmenopozal kadın (ortalama yaş $53,9 \pm 9)$ hasta retrospektif olarak dahil edildi. Uygun bulunan toplam 87 vertebra T skorlarına göre normal, osteopeni, osteporoz olarak alt gruplara ayrıldı. DAG'den görünür difüzyon katsayısı (ADC) değerleri hesaplandı. T1 dual-eko sekanslardaki sinyal yoğunlukları ölçülerek gruplar arasında karşılaştııılı. Vertebra korpuslarının yağ yüzdeleri daha önceden adrenal adenomlar için kullanılan sinyal yoğunluk indeksi (SYi) ve vertebra dalak oranı (VDO) formülleri üzerinden hesaplandı.

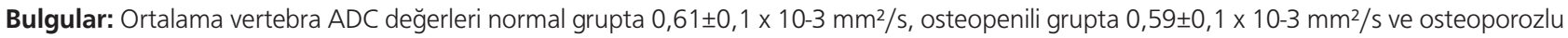
grupta $0,56 \pm 0,1 \times 10-3 \mathrm{~mm}^{2} / \mathrm{s}$ ölçüldü ve aralarında anlamlı farklılık ortaya çıkmadı. Out of faz sekansındaki sinyal yoğunluğu, SYi ve VDO artmış kırık riski bulunan osteoporozlu grubu sağlıklı ve osteopenili gruptan ayırabildi. Out of faz sinyal yoğunluğu, SYi, ve VDO'nun duyarlııkları sırasıyla \%65,2, \%61,1, ve \%71, iken, özgüllükleri \%61,1, \%63,8 ve \%61,1 bulundu.

Sonuç: Kemik iliğinin difüzyon özellikleri osteoporozdan tam olarak etkilenmemektedir. DXA skorları kemik iliğinin selülaritesinden çok kimyasal bileşimiyle orta derece ilişkili gözükmektedir. Kimyasal kayma görüntülemeye dayalı yağ kantifikasyonu osteoporozun varlığına dair fikir vererek tedaviye başlamaya karar verme aşamasında yönlendirici olabilir.

Anahtar kelimeler: Osteoporoz, kemik mineral yoğunluğu, manyetik rezonans görüntüleme, kimyasal kayma görüntüleme, difüzyon ağırlıklı görüntüleme

Address for Correspondence/Yazıșma Adresi: Betül Kızıldağ MD,

Kahramanmaraş Sütçü Imam University Faculty of Medicine, Department of Radiology, Kahramanmaraş, Turkey

Phone: +90 5052556461 E-mail: betulkizildag@hotmail.com ORCID ID: orcid.org/0000-0002-2567-4330

Received/Geliș Tarihi: 14.02.2018 Accepted/Kabul Tarihi: 24.10.2018

${ }^{\circ}$ Copyright 2018 by the Turkish Osteoporosis Society

Turkish Journal of Osteoporosis published by Galenos Yayınevi. 


\section{Introduction}

Osteoporosis as a systemic skeletal problem characterized by reduction in bone strength which makes the bones more susceptible to fractures (1). Trabecular bone features, including the architecture, connectivity or response to fatigue, damage, and repair, specify the quality of bone, while the bone density determines the rate of bone mass reduction from a peak level (2). Osteoporosis affects a large component of the elderly population, at a rate of $40 \%$ in women and $20 \%$ in men older than 50 years of age (3). In addition, it causes significant morbidity, mortality and cost in the relevant population, leading to pain and immobilization, as well as life threatening complications from fractures (4). Dual-energy X-ray absorptiometry (DXA) is a non-invasive tool that uses ionizing radiation and is commonly used for the diagnosis of osteoporosis. This diagnosis is established according to the T-score, which calculates the difference between a patients bone density and that of a healthy 30 year-old individual. The World Health Organization (WHO) recommends the T-score as the best predictor for diagnosing osteoporosis (5), although DXA may reflect artifacts in patients with vertebral fractures, scoliosis and degenerative hypertrophic changes. Therefore, magnetic resonance imaging (MRI) has been suggested to provide knowledge about the bone quality as a potential factor in osteoporosis, due to its ability to characterize diffusion and perfusion properties and quantify the fatty marrow of bone. Previous studies have reported high vertebral fat marrow in osteoporotic patients, indicating rarefaction of the trabeculae by MR spectroscopy $(3,6-8)$ chemical shift imaging (CSI), dualecho $(9,10)$ and multi-echo techniques $(11)$, or low perfusion via dynamic contrast enhanced studies $(3,6)$. There have been few studies investigating diffusion weighted MR changes $(3,7,11$ 13), and those results were controversial. For example, Griffith et al. (3), showed no correlation in their apparent diffusion coefficients (ADC) results, while Tang et al. (7), Hatipoglu et al. (13), and Yeung et al. (12) demonstrated positive correlations between the ADC values and bone density values in postmenopausal women.

In this study, we aimed to investigate whether or not diffusion MRI can be used for the diagnosis of osteoporosis. For this purpose, the relationship between the ADC and bone mineral density (BMD) in multiple lumbar vertebrae were further analyzed. The ADC values were derived from the tetrahedral diffusion weighted image (DWI), a more recent/newer isotropic diffusion weighted MR technique that provides high spatial resolution with higher b values (14). And secondly to investigate the relationship between the vertebral signal intensity (SI) index and vertebral-splenic ratio (VSR) was adapted from the formula for the quantification of fat in adrenal adenomas (15), as a marker for the lumbar vertebral fat content derived from a dualecho chemical-shift MRI.

\section{Materials and Methods}

\section{Patient Selection}

Twenty-nine consecutive postmenopausal patients referred to the radiology department for both upper abdominal MRI and DXA imaging for various reasons (hepatic hemangioma, adrenal adenoma, renal cyst, pancreatic cyst, etc.) within 1 month, between December of 2014 and February of 2016 at an university hospital were included in this study retrospectively. Patients with known metabolic bone disease, bone metastasis (with clinical or imaging evidence), previous spinal surgery, giant Schmorl's nodule, hematological disease or malignancy, compression fracture, hemangioma, or focal fatty infiltration were not included in this research.

For each patient, the height, weight, body mass index (BMI), were noted.

\section{Radiological Studies}

The DXA examinations were done with an anteroposterior projection (Hologic QDR-4500W; Hologic, Waltham, MA) of four lumbar vertebrae (L1 to L4) to obtain the average bone density in $\mathrm{g} / \mathrm{cm}^{2}$ from each vertebra. The T-score was calculated on the basis of data from the local population. Based on the WHO criteria, a T-score $>-1$ is normal, T-score $\leq 2.5$ shows osteoporosis, and T-score from -1 to 2.5 shows osteopenia. As independent samples, the BMD $\left(\mathrm{g} / \mathrm{cm}^{2}\right)$ and T-score were noted for each vertebra.

The upper abdominal MR examinations were performed with a 1.5 Tesla scanner (Optima MR360 1.5 T; GE Healthcare, Milwaukee, $\mathrm{WI})$. The maximum gradient strength of the system was $33 \mathrm{mT} / \mathrm{m}$, with a rate of peak slew at $120 \mathrm{mT} / \mathrm{m} / \mathrm{msec}$. A body array coil was used for the upper abdominal examination, and an echo planar imaging tetrahedral sequence of DW images was acquired with a TE of $53 \mathrm{~ms}$ and a b-factor of 600 $\mathrm{s} / \mathrm{mm} 2$ in an axial plan. The following parameters were used: time of repetition (TR) $7149 \mathrm{~ms}$, time of echo (TE) $80.6 \mathrm{~ms}$, slice thickness $6 \mathrm{~mm}$, interslice gap $1 \mathrm{~mm}$, field of view $42 \times 42 \mathrm{~cm}$, matrix 80x128, and number of excitations (NEX) 2.00.

Moreover, spin-echo fast spoiled gradient echo recall T1 weighted dual-echo images were obtained with the following parameters: TR $215 \mathrm{~ms}$, TE $2.1 \mathrm{~ms}$, slice thickness $6 \mathrm{~mm}$, interslice gap $1.0 \mathrm{~mm}$, field of view $42 \times 37.8 \mathrm{~mm}$, matrix $320 \times 160$ and NEX 1.0.

\section{Data Analysis}

The images were analyzed at a workstation (Intellispace Portal, Philips v 6.03.13200; Philips Healthcare Nederland B.V., Best, Netherlands) by two radiologists with more than 10 years of MRI experience. Each of the vertebra was accepted to be an independent sample. On the DWI images, for each lumbar vertebra from $L 1$ to $L 4$, an ellipsoid region of interest (ROI) was drawn manually on the transverse slice from the mid-vertebral 
level, at least $3 \mathrm{~mm}$ away from the contours of the vertebra and far from basivertebral vein slice (Figure 1). The mean ADC values for each vertebra were recorded.

On the dual-echo chemical shift images, the ROI was drawn on the same level in order to record the SI of every vertebra in-phase and corresponding out-of-phase sequence using the copy and paste function on the workstation (Figure 2). A circular $\mathrm{ROI}$ was also placed on the spleen parenchyma, away from the artefact or vessel in both opposite sequences, to measure the SI. The SI index and ASR formulas that were used to measure the lipid content of the adrenal adenomas were adapted to measure the fat fraction of the vertebral body in this study (15). We used the following formula for the vertebrae: SI index $=\mathrm{VI}$ VO*100/VI. The VSR formula was: VSR=VO/SO $\div \mathrm{VI} / \mathrm{SII}$. In these formulas, the SII was the SI of the spleen on an in-phase image, the SO was the SI of the spleen on an out-of-phase image, the VI was the SI of a vertebra on an in-phase image, and the VO was the SI of a vertebra on an out-of-phase image. Study workflow diagram regarding patient selection, measurements and subgroups are being demonstrated in Figure 3.

\section{Statistical Analysis}

The statistical analyses evaluated the demographic, physical, and laboratory examination findings by using the mean and standard deviation for the numeric variables and percentage distributions for the categorical ones. The analyses used to compare the normally distributed independent variable groups were the One-Way ANOVA test. The post-hoc analyses were performed with the One-Way ANOVA and Tukey's tests, and the correlations between the variables were analyzed with Pearson correlation tests. The analyses were performed with SPSS version 12.0 (Chicago, IL), and values of $p<0.05$ were considered to be statistically significant.

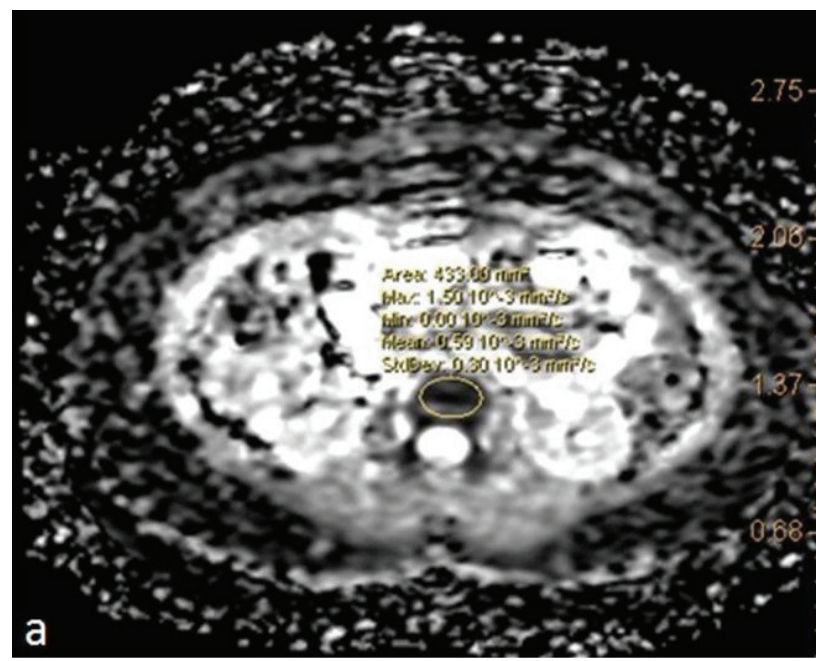

Figure 1. Placement of region of interest is being shown during measurement of apperant diffusion coefficients (a) values from corpus of first lumbal vertebra of a 59 year- old woman in osteoporotic group according to T score (-3.4)

\section{Results}

A total of 29 patients (postmenopausal women) that underwent both DXA and upper abdominal MR examinations were enrolled in this study. The mean age of the participants was $53.9 \pm 9$ years old, the median age was 55, and the range was 38 to 72. The mean time interval between the DXA and MRI was 28 days and those patients with time intervals longer than 1 month were not included. One patient with bone metastasis and one patient with posterior instrumentation were also excluded.

The mean BMl of the subjects was $30.4 \pm 5.2 \mathrm{~kg} / \mathrm{m}^{2}$. According to the BMI scores, 7 of the patients $(24.6 \%)$ were within normal limits, 6 (20.6\%) were overweight, and 16 (55.1\%) were obese. No significant differences were observed among the three groups.

Twenty-nine lumbar vertebrae were not included in this research, because the images were not within the field of view. Both the T1 in-phase images and coronal fast imaging employing steadystate acquisition images had optimal image qualities for the anatomical depiction of the mid-lumbar vertebrae. In total, 87 vertebrae were available for measurements in the current study. The mean BMD of the group was $0.860 \pm 0.15 \mathrm{~g} / \mathrm{cm}^{2}$. According to the WHO criteria based on the T-score, 24 vertebrae were healthy $(27.5 \%), 45$ vertebrae were osteopenic $(51.7 \%)$, and 18 vertebrae (20.6\%) were osteoporotic.

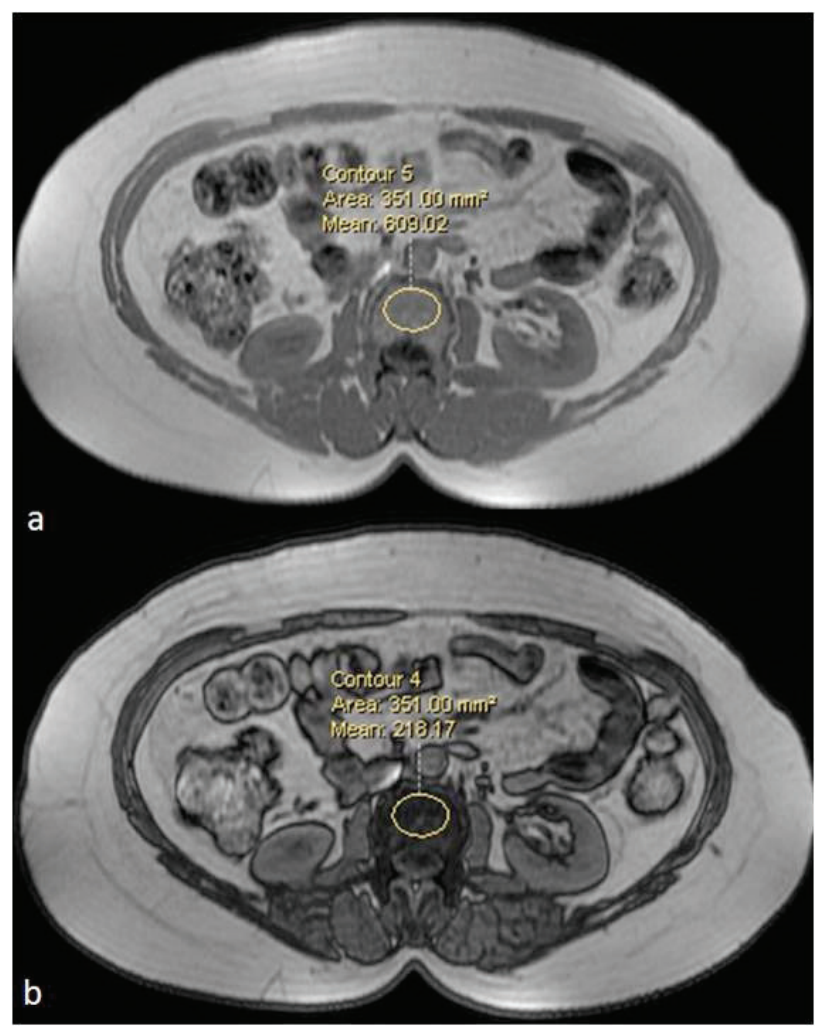

Figure 2. Placement of region of interest is being shown during measurement of $\mathrm{T} 1$ dual echo sequences in-phase (a) and out-of phase (b) respectively from corpus of first lumbal vertebra of a 59 year- old woman in osteoporotic group according to T score (-3.4) 
Table 1 is showing the mean vertebral fat marrow SIs on the T1 dual echo in-phase images, out-of-phase images, SI index and VSR for each group in terms of their WHO classifications. Comparisons within the three groups revealed no significant differences.

When we compared the previous parameters among the osteoporotic vertebrae with the other combined groups (normal and osteopenic), the results revealed significant differences in terms of the T1 dual-echo out-of-sequence SI ( $p=0.41)$, and SI index $(p=0.21)$, as well as the VSR $(p=0.21)$ and splenic $S I$ in the out-of-phase sequence $(p=0.27)$ (Table 2$)$. According to ROC analysis; when we used the cut-off values of 209 for the out-of-phase (area under curve 0.67, 0.95; 95\% confidence interval: $0.53,0.82$ ), $>63.5 \%$ for the $\mathrm{SI}$ index (area under curve $0.68,0.95$; $95 \%$ confidence interval: $0.53,0.82)$, and $<0.35$ for the VSR (area under curve 0.67, 0.95; 95\% confidence interval:

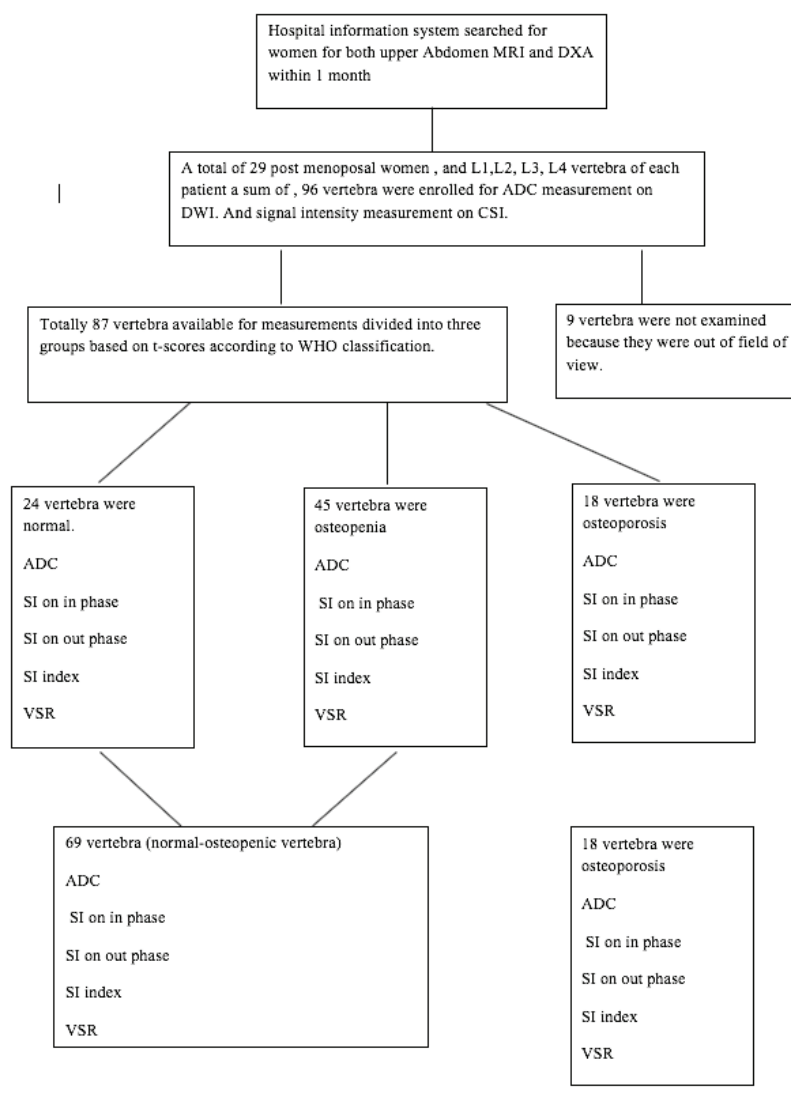

Figure 3. Study workflow diagram regarding patient selection, measurements and subgroups [ADC (apperant diffusion coefficients), SI (signal intensity), VSR (vertebra spleen ratio)]
$0.58,0,85)$; the sensitivities of the out-of-phase SI, SI index and VSR were $65.2 \%, 61.1 \%$, and $71 \%$, respectively, while the specificities were $61.1 \%, 63.8 \%$, and $61.1 \%$, respectively, for discriminating osteoporotic patients.

The mean vertebral ADCs were $0.61 \pm 0.1 \times 10-3 \mathrm{~mm}^{2} / \mathrm{s}$ in the normal, $0.59 \pm 0.1 \times 10-3 \mathrm{~mm}^{2} / \mathrm{s}$ in the osteopenic, and $0.56 \pm 0.1 \mathrm{x}$ $10-3 \mathrm{~mm}^{2} / \mathrm{s}$ in the osteoporotic vertebrae. We measured mildly decreasing ADCs from the normal vertebrae to the osteoporotic ones, but no significant difference was noted among the groups in terms of both the ADC values.

There were no significant differences among the normal, overweight, and obese patients in terms of in-phase and out-ofphase SIS, ADC, SI index, VSR and BMD values.

According to data including sample volume $n 1: 18$ and $n 2$ : 69 , with an error level a: 0.05, power analysis of study was calculated as 0.86 .

\section{Discussion}

Based on the results of our study, DWI was not able to separate the healthy lumbar vertebrae from the osteopenic or osteoporotic ones; although it did reveal a decline in the ADC values from the healthy to the osteoporotic group. Interestingly, the bone marrow fat content has been reported to be increased in patients with osteoporosis $(3,6-8)$. In this study, it was calculated based on the formulas used to measure the ratio and percentage of the lipid content of adrenal adenomas from chemical shift MRI (15). Moreover, our results showed that the measurements based on signal discard, including the SI in-phase, SI out-of-phase, SI index and VSR of the vertebrae, did not have the ability to distinguish between the healthy, osteopenic, and osteoporotic vertebrae (Table 1). Nevertheless, the out-of-phase SI, SI index, and VSR were able to discriminate the osteoporotic vertebrae that had sustained fracture risks from the other two (healthy and osteopenic) (Table 2).

The DWI depends on the restriction of the Brownian randomized motion of the water molecules, and is quantified by the ADC values. It is primarily affected by the tissue cellularity, interstitial space width and partially perfusion. The determination of the correlation between the diffusion indexes of the vertebral bone marrow and BMD offers a valuable opportunity for the diagnosis of osteoporosis via DWI as a fast MRI method without ionizing radiation. Old age, menopause stage and osteoporosis are conditions associated with increased bone marrow fat $(7,16)$; and in osteoporosis, diffusion restriction has been suggested to be due to the reduction of the interstitial

\section{Table 1. Shows the mean vertebral fat marrow signal intensitys on the T1 dual echo in-phase images, out-of-phase images, signal intensity index and} vertebra spleen ratio for each group in terms of their world health organization classifications

\begin{tabular}{|c|c|c|c|c|c|c|c|c|}
\hline WHO & BMD & T-score & SI in-phase & SI out-of phase & SI index \% & VSR & Spleen IP & Spleen OP \\
\hline Normal $($ mean \pm SD) & $0.98 \pm 0.09$ & $-0.19 \pm 0.7$ & $533 \pm 79$ & $224 \pm 81$ & $58 \pm 1$ & $0.48 \pm 0.2$ & $454 \pm 75$ & $409 \pm 78$ \\
\hline Osteopenia & $0.85 \pm 0.09$ & $-1.82 \pm 0.4$ & $596 \pm 91$ & $278 \pm 11$ & $53 \pm 1$ & $0.52 \pm 0.1$ & $466 \pm 69$ & $451 \pm 77$ \\
\hline Osteoporosis & $0.71 \pm 0.1$ & $-3.04 \pm 0.5$ & $564 \pm 13$ & $202 \pm 88$ & $64 \pm 1$ & $0.38 \pm 0.1$ & $424 \pm 69$ & $390 \pm 71$ \\
\hline
\end{tabular}


space because of excessive fat cells (12). In addition, the motion of the interstitial fluid stimulates anabolic processes by activating the mediators (17). Griffith et al. (3) suggested that decreased motion might cause diffusion restriction and low bone production in osteoporotic bones. The previously demonstrated lower perfusion indexes (3) might also promote lower ADC values. In contrast to previous studies, these assessed a significant relationship between the BMD and diffusion properties $(7,12,13)$, our results supported the previous studies that stated no significant difference in terms of the ADC values among the groups classified according to the WHO classification based on T-scores (3). Tang et al. (7) reported significant correlations between the BMD and $A D C$ values, and that osteoporotic patients showed restricted diffusion in post-menopausal women. They used sagittal images and measurements at the L3 vertebra level, with lower b-values $(b=300)$. In addition, Hatipoglu et al. (13) found similar results using a b-value of 600. Different b-values can be administered by changing the gradient amplitudes, and higher b-values can sense the slower flow of fluid. Griffith et al. (3) used different b-values and measurements on the axial plane, from the corpus of the L3 vertebra, and they reported no significant differences among the subgroups. We do not believe that these contrary results emerged from the b-values only. We also used the axial plane and tried to exclude the basivertebral vein slice in order to exclude the perfusion effects. The mean ADC values of the healthy, osteopenic, and osteoporotic vertebrae were $0.61 \times 10$ $3,0.59 \times 10-3$, and 0.56×10-3, respectively, which showed a decline from the healthy to the osteoporotic group, but did not seem to be significant.

The bone marrow fat content has been shown to be increased in osteoporosis, according to previous studies using MR spectroscopy $(3,6-8)$. Here, we used the CSI as a magnitude technique based on signal discarding for intravoxel fat detection, which depends on the fact that water and lipid molecules resonate at different frequencies. It is composed of two opposite sequences, in which the in-phase sequence is based on the alignment of signals from the water and lipid molecules. When they are contradictory, the signals are removed from each other, so that an out-of-phase sequence reduction is seen in the signal due to the lipid fraction. Therefore, the yellow marrow, which is full of fatty cells, instead of red marrow, which is full of hematopoietic cells, will lose signal in out-of-phase sequences. Schellinger et al. (8). reported that bone marrow fat, as a new measure to diagnose reduced bone strength, worked nearly as well as the BMD. In addition, Maas et al. (18). reported that the CSI was a reproducible technique for fat quantification. Therefore, we investigated the feasibility of CSI based fat quantification in the diagnosis of osteoporosis, since the CSI provides a faster measurement of fat and allows for the analysis of more than one vertebra. Youn et al. (9) and Gokalp et al. (10) did not demonstrate any significant differences among the normal, osteopenic, and osteoporotic groups. Different from the abovementioned procedures, in the current study we used the SI index and ASR formulas for the quantification of the fat ratio during the diagnosis of adrenal adenomas. We adapted them for the vertebrae as the VSR and vertebral SI index. The measurements of the in-phase SI, out-of-phase SI, calculated vertebral SI index, and VSR values were unable to distinguish among the 3 groups (Table 1). These results were all parallel to previous results and could be explained by the concept that the CSI may underestimate the fat fraction by $15 \%$ percent due to presence of neutral fats, which carry protons without methyl groups (18). Also it has been shown that the saturated lipids increase preferentially to the unsaturated lipids in fatty bone marrow (19). However, factors affecting the relaxation effects from the T1 and T2 and the multispectral distribution of fat, noise, and eddy currents may contribute the SI changes in these vertebrae (11). CSI has ability to demonstrate fat up to in $50 \%$ fat fraction and for quantification of excess fat fractions complex based fat fraction methods were offered recently (11). In osteoporotic patients ( $T$-score $<2.5$ ), medical treatments are offered based on specific guidelines (4). From this point, we constructed two groups (osteoporotic patients and healthy or osteopenic patients) and compared them in terms of signal changes. The osteoporotic vertebrae showed significantly lower measurements in terms of the out-of-phase SI, SI index, and higher VSR values (Table 2). The out-of-phase SI, SI index, and VSR were able to discriminate the osteoporotic vertebrae that have sustained fracture risk from the healthy and osteopenic ones. The sensitivities of the vertebral SI out-of-phase sequence, SI index, and VSR were $65.2 \%, 61.1 \%$, and $71 \%$, respectively, while the specificities were $61.1 \%, 63.8 \%$, and $61.1 \%$, respectively, when we used the cut-off values of 209,035 for the out-of-phase SI, 0.635 for the SI index, and 35.5\% for the VSR. We suggest that those osteoporotic patients who are asymptomatic (unless a fracture occurs) can be identified while interpreting upper abdominal MRI for other reasons. Radiologists should measure the SI in the CSI, and consider the existence of osteoporosis in the relevant population, in order to direct the patients for medical treatment.

\section{Study Limitations}

This study was limited because of its retrospective manner, low patient number, and the acceptance of one vertebra as a single sample. DXA was used as a reference technique to

\begin{tabular}{|c|c|c|c|c|c|c|}
\hline WHO & SI in-phase & SI out-of phase & SI index (\%) & VSR & Spleen IP & Spleen IP \\
\hline Osteoporotic & $564 \pm 130$ & $202 \pm 88^{*}$ & $64 \pm 1^{*}$ & $0,38 \pm 1^{\dagger}$ & $424 \pm 69$ & $390 \pm 71$ \\
\hline Normal \& osteopenic & $574 \pm 92$ & $259 \pm 10^{*}$ & $54 \pm 1^{*}$ & $0,50 \pm 2^{\dagger}$ & $461 \pm 71$ & $437 \pm 79$ \\
\hline
\end{tabular}


non-invasively measure the BMD, but it does not measure other factors that may contribute to the bone strength, including the microarchitecture. The T-score was accepted as only one value per person, but we saw that the vertebral BMD scores were not equal in the same patient. Furthermore, those patients taking medication for osteoporosis were ignored.

\section{Conclusion}

Consequently, the diffusion properties of bone marrow are not fully affected by osteoporosis. The BMD scores moderately correlated the chemical composition of bone marrow, instead of tissue cellularity. CSI based fat quantification should provide an idea about the presence of osteoporosis and should direct the initiation of treatment in a patient.

\section{Ethics}

Ethics Committee Approval: Retrospective study.

Informed Consent: Informed consent was obtained from all patients before magnetic resonance imaging.

Peer-review: Externally and internally peer-reviewed.

\section{Authorship Contributions}

Surgical and Medical Practices: M. A. S, N. Y., Concept: B. K., Design: B. K., Data Collection or Processing: M. A. S., Analysis or Interpretation: B. K., Literature Search: N. Y., Writing: B. K.

Conflict of Interest: No conflict of interest was declared by the authors.

Financial Disclosure: The authors declared that this study received no financial support.

\section{References}

1. NIH Consensus Development Panel on Osteoporosis Prevention, Diagnosis, and Therapy. Osteoporosis prevention, diagnosis, and therapy. JAMA 2001;285:785-95.

2. Lentle BC, Prior JC. Osteoporosis: What a clinician expect to learn from a patient's bone density examination. Radiology 2003;228:620-8.

3. Griffith JF, Yeung DK, Antonio GE, Wong SY, Kwok TC, Woo J, et al. Vertebral marrow fat content and diffusion and perfusion indexes in women with varying bone density: MR evaluation. Radiology 2006;241:831-8.

4. U.S. Preventive Services Task Force. Screening for osteoporosis: U.S. preventive services task force recommendation statement. Ann Intern Med 2011;154:356-64.

5. Blake GM, Fogelman I. The role of DXA bone densityscans in the diagnosis and treatment of osteoporosis. Postgraduate Med J 2007;83:509-17.
6. Griffith JF, Yeung DK, Antonio GE, Lee FK, Hong AW, Wong SY, et al. Vertebral bone mineral density, marrow perfusion, and fat content in healthy men and men with osteoporosis: dynamic contrast-enhanced MR imaging and MR spectroscopy. Radiology 2005;236:945-51.

7. Tang GY, Lv ZW, Tang RB, Liu Y, Peng YF, Li W, et al. Evaluation of MR spectroscopy and diffusion-weighted MRI in detecting bone marrow changes in postmenopausal women with osteoporosis. ClinRadiol 2010;65:377-81.

8. Schellinger D, Lin CS, Lim J, Hatipoglu HG, Pezzullo JC, Singer AJ. Bone marrow fat and bone mineral density on proton MR spectroscopy and dual-energy X-ray absorptiometry: the ratio as a new indicator of bone weakening. AJR Am J Roentgenol 2004;183:1761-5

9. Youn I, Lee HY, Kim JK. Correlation between vertebral marrow fat fraction measured using dixon quantitative chemical shift MRI and BMD value on Dual Energy $X$ ray absorptiometry. J Korean Soc Mag Reson Med 2012;16:16-24.

10. Gokalp G, Mutlu FS, Yazıcı Z, Yildirim N. Evaluation of vertebral bone marrow content by chemical-shift MRI in osteoporosis. Skeletal Radiol 2011;40:577-85.

11. Kühn JP, Hernando D, Meffert PJ, Reeder S, Hosten N, Laqua R, et al. Proton-density fat fraction and simultaneous R2* estimation as an MRI tool for assessment of osteoporosis. Eur Radiol 2013;23:3432-9.

12. Yeung DK, Wong SY, Griffifth JF, Lau EM. Bone marrow diffusion in osteoporosis: evaluation with quantitive MR diffusion imaging. J Magn Reson Imaging 2004;19:222-8.

13. Hatipoglu HG, Selvi A, Ciliz D, Yuksel E. Quantitative and diffusion MR imaging as a new method to assess osteoporosis. AJNR Am J Neuroradiol 2007;28:1934-7.

14. Hori M, Kim T, Murakami T, Onishi H, Tsuboyama N, Osuga $K$, et al. Anisotropic Diffusion-weighted MR imaging with tetrahedral gradients in the upper abdomen. Magn Reson Med Sci 2006;5:201-6.

15. Fujiyoshi F, NAkoja M, Kukukura Y, Tsuchimochi S. Characterization of adrenal tumors by chemical shift fast-low angle shot MR imaging: comparison of four methods of quantitative evaluation. AJR 2003;180:1649-57.

16. Justesen J, Stenderup K, Ebbesen EN, Mosekilde L, Steiniche T, Kassen M. Adipocyte tissue volume in bone marrow is increased with aging and in patients with osteoporosis. Biogerontology 2001;2:167-71.

17. Sterck JG, Klein-Nulend J, Lips P, Burger EH. Response of normal and osteoporotic human bone cells to mechanical stress in vitro. Am J Physiol Endocrinol Metab 1998;214:E1113-E20.

18. Maas M, Akkerman EM, Venema HW, Stoker J, Den Heeten GJ. Dixon quantitative chemical shift MRI for bone marrow evaluation in the lumbar spine: a reproducibility study in healthy volunteers. J Comput Assist Tomogr 2001;25:691-7.

19. Yeung DK, Griffith JF, Antonio GE, Lee FK, Woo J, Leung PC. Osteoporosis is associated with increased marrow fat content and decreased marrow fat unsaturation: a proton MR spectroscopy study. J Magn Reson Imaging 2005;22:279-85. 